\title{
Cephalopod predation by the king penguin Aptenodytes patagonicus from South Georgia
}

\author{
P. G. Rodhouse ${ }^{1, *}$, O. Olsson ${ }^{1,2}$, P. Anker-Nilssen ${ }^{3}$, A. W. A. Murray ${ }^{1}$ \\ 'British Antarctic Survey, Natural Environment Research Council, Hígh Cross, Madingley Road, Cambridge CB3 0ET, \\ United Kingdom \\ ${ }^{2}$ Department of Zoology, Villavägen 9, Uppsala University, S-752 36 Uppsala, Sweden \\ ${ }^{3}$ Department of Marine Zoology, University of Oslo, PO Box 1050, N-0316 Blindern, Norway
}

\begin{abstract}
The king penguin Aptenodytes patagonicus is a sub-Antarctic species that feeds primarily on mesopelagic fish and cephalopods in the vicinity of the Antarctic Polar Front (APF). We examined the cephalopod prey of adult penguins at a breeding colony on South Georgia during 4 austral summers, 1990 to 1994 . The most important prey ( $-97 \%$ by mass $)$ of the king penguins was found, in a related study, to be mesopelagic fish, mainly myctophids. The penguins' cephalopod prey, which constituted the remaining $3 \%$, was shown in this study to be dominated by the ommastrephid squid Martialia hyadesi, both in terms of numbers and biomass. Other squid species were typical of the South Georgia/Antarctic Polar Front (APF) area but only relatively small specimens were present and, apart from Gonatus antarcticus, the presence of flesh indicated that they were probably mostly caught close to the island. $M$. hyadesi generally fell in the same size range as $M$. hyadesi exploited by commercial fisheries in the South Atlantic. In the 1992/93 summer, when krill was abundant at South Georgia, the amount of squid consumed, especially $M$. hyadesi, was substantially less than in the other years. This coincided with a reduction in the amount of the myctophid Krefftichthys anderssoni, which is the major prey of $M$. hyadesi, in the penguin diet. The total consumption of cephalopods by the king penguin at

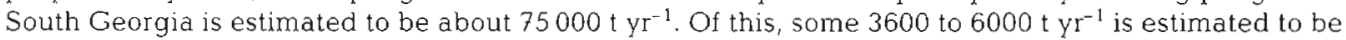
$M$. hyadesi. This might underestimate consumption if the penguins consume a greater proportion of squid in the winter, as they do in other sectors of the Southern Ocean.
\end{abstract}

KEY WORDS: Cephalopods - King penguins Oceanography · South Georgia

\section{INTRODUCTION}

King penguins Aptenodytes patagonicus are distributed throughout the sub-Antarctic and they breed on most of the peri-Antarctic islands. King penguins feed almost exclusively on mesopelagic fish and pelagic cephalopods. The importance of cephalopods in the diet changes seasonally. Recent data from samples taken at South Georgia, using the water off-loading technique, have shown that cephalopods contribute about $3 \%$ of the total mass of food consumed in summer and, at this time of year, the diet is dominated by myctophids (Olsson \& North 1997). Elsewhere, at the peri-Antarctic islands of Possession (Crozet Archipelago) and Marion, research has shown that myctophids

\footnotetext{
•E-mail:p.rodhouse@bas.ac.uk
}

are the major prey but, during winter, the importance of cephalopods as prey increases and they may contribute up to $64 \%$ of the total wet mass of food consumed (Adams \& Klages 1987, Cherel et al. 1996). The trophodynamics of king penguins are of particular interest as their populations have been increasing steadily at almost all sites over at least the last $30 \mathrm{yr}$. At South Georgia the population has increased from about 2000 pairs in 1914 to 100000 pairs in 1986 (Croxall et al. 1988) to about 400000 pairs today (comprising some $25 \%$ of the world population) (P. A. Prince pers. comm.).

Whilst breeding, king penguins may forage over distances of up to $1200 \mathrm{~km}$ from the colony. From Possession Island in the Indian Ocean sector, they frequently forage in the direction of the Antarctic Polar Front (APF) (ca $300 \mathrm{~km})$, to the south of the island, where it is assumed there is a predictable food resource (Jou- 
ventin et al. 1994). King penguins are effective divers. During the day they forage at depths of 100 to $300 \mathrm{~m}$ and at night they feed near the surface $(<30 \mathrm{~m}$ ) (Kooyman et al. 1992). This is consistent with their preying on the mesopelagic nekton community which, in the sub-Antarctic, largely migrates from circumpolar deep water (>200 to $300 \mathrm{~m}$ ), where it remains during daylight, to Antarctic surface water at night (Piatkowski et al. 1994).

Until recently the biology of the Antarctic Polar Frontal Zone (APFZ) has received little attention, and this very large, remote region has generally been assumed to be relatively unproductive (Hempel 1985). Recent research has shown, however, that an important ecosystem exists in the Atlantic sector of the APFZ (Piatkowski et al. 1994, Rodhouse et al. 1994a, Pagès 1996). Squid are the top pelagic predators, replacing epipelagic fish, which are absent in these waters. The squid feed mainly on mesopelagic fish, which in turn feed on copepods and other small crustaceans (Rodhouse et al. 1992b). Satellite tracking has shown that squid predators breeding at South Georgia, notably grey-headed albatrosses (Rodhouse et al. 1996, Prince et al. 1997) and southern elephant seals (McConnell \& Fedak 1996), regularly forage in the APFZ.

The most abundant squid in the Atlantic sector of the APFZ is the ommastrephid Martialia hyadesi (Rodhouse \& White 1995). The $M$. hyadesi stock in the CCAMLR (Commission for the Conservation of Antarctic Marine Living Resources) area appears to be large enough to support a fishery, provided adequate precautionary measures are taken (Rodhouse 1997). It is likely that a new fishery will develop in the future and so information about interactions of $M$. hyadesi with other dependent predator species, including king penguins, is of special interest.

In this paper we present data on the cephalopod prey of king penguins sampled at South Georgia over 4 summer seasons between 1990 and 1994, with special emphasis on interannual variability. This is particularly relevant because the period in question was marked by substantial fluctuations in the size of the Antarctic krill Euphausia superba stock in the area, which had important effects on the ecology of the krilldependent higher predators breeding at South Georgia (Croxall et al. 1997, Reid et al, 1997). In 1993/94, 4 king penguins were satellite tracked, and we discuss the known distribution of the cephalopod prey in relation to the foraging areas of these penguins.

\section{METHODS}

Food samples were collected from the colony of about 4000 pairs of king penguins at Fortuna Bay,
South Georgia, over 4 summer seasons between 1990 and 1994. In 1990/91, 18 penguins were sampled once in January, whereas during the following 3 years samples were taken throughout the summer (OIsson \& North 1997). Stomach contents from a total of 139 different penguins returning from the sea to feed the chick(s) were taken using procedures described by Wilson (1984), Hindell (1988) and Olsson \& North (1997). Measurements of the relative proportions of fish and squid in the diet were based on the flesh mass of the 2 categories of food, assuming equal digestion rates.

Cephalopod beaks were removed from the samples and lower beaks identified by comparison with beaks from squid caught by nets and jigs in the Scotia Sea and by reference to Clarke (1986). Lower rostral lengths (LRL) of beaks were measured to $0.1 \mathrm{~mm}$ with Vernier calipers. Allometric equations given by Clarke (1986) and Rodhouse et al. (1990) were used to estimate mantle length (ML) and wet body mass (BM) from LRL. Beaks were also assigned to 1 of 4 categories: (1) with flesh still attached, identifiable and measurable, (2) without flesh, identifiable and measurable, (3) without flesh, identifiable but unmeasurable, (4) unidentifiable and unmeasurable. The presence of flesh was not recorded in the first year of the study.

In $1993 / 94,4$ penguins were fitted with Toycom 2038 microwave platform terminal transmitters (PTTs) weighing between 65 and $75 \mathrm{~g}$. These were attached using the method described by Prince et al. (1992). PTT data from the tagged penguins were relayed to Toulouse (France) via the Argos satellite system and sent daily to BAS headquarters in Cambridge (UK). The PTT positional information was loaded into PC Arc/Info (ESRI), a geographical information system (GIS). Plots of individual foraging trips, and a compilation of all trips, were generated with the GIS.

\section{RESULTS}

\section{Cephalopod species}

Cephalopod species identified from beaks in the regurgitations of king penguins are listed for each year of the study in Table 1. Numbers are for all samples from all penguins combined for each year. All the cephalopods in the diet were squid; there were no octopodids. A total of 2706 beaks was counted; 2021 beaks were identified and 1451 beaks were measured. Measured beaks represented an estimated total of $250 \mathrm{~kg}$ of squid wet mass. A relatively large proportion of the beaks collected $(25 \%)$ were unidentifiable because they were too damaged or degraded. Further- 
Table 1 Aptenodytes patagonicus. Cephalopod beaks found in the stomach contents of 134 king penguins sampled at South Georgia during 4 austral summers (cephalopod species ranked in order of importance in terms of mass for all years combined; values in parentheses are percentages; $n$ : number of king penguins sampled)

\begin{tabular}{|lcccccccc|}
\hline Cephalopod species & $\begin{array}{c}1990 / 91 \\
\text { No. }\end{array}$ & $\begin{array}{c}\mathrm{n}=18 \\
\text { No. measurable }\end{array}$ & $\begin{array}{c}1991 / 92 \\
\text { No. }\end{array}$ & $\begin{array}{c}\mathrm{n}=67 \\
\text { No. measurable }\end{array}$ & $\begin{array}{c}1992 / 93 \\
\text { No. }\end{array}$ & $\begin{array}{c}\mathrm{n}=20 \\
\text { No. measurable }\end{array}$ & $\begin{array}{c}1993 / 94 \\
\text { No. }\end{array}$ & $\begin{array}{c}\mathrm{n}=34 \\
\text { No. measurable }\end{array}$ \\
\hline Martialia hyadesi & $394(45)$ & $154(56)$ & $401(52)$ & $187(42)$ & $22(18)$ & $18(18)$ & $255(26)$ & $218(35)$ \\
Moroteuthis knipovitchi & $18(2)$ & $17(6)$ & $63(8)$ & $63(14)$ & $16(13)$ & $16(16)$ & $155(16)$ & $88(14)$ \\
Kondakovia longimana & $71(9)$ & $66(24)$ & $65(8)$ & $65(15)$ & $33(27)$ & $33(34)$ & $209(22)$ & $209(33)$ \\
Psychroteuthis glacialis & $31(4)$ & $29(11)$ & $107(14)$ & $107(24)$ & $26(21)$ & $26(26)$ & $58(6)$ & $58(9)$ \\
Alluroteuthis antarcticus & $1(<1)$ & $1(<1)$ & $5(<1)$ & $5(1)$ & $1(<1)$ & $1(1)$ & $21(2)$ & $21(3)$ \\
Gonatus antarcticus & 0 & 0 & $5(<1)$ & $5(1)$ & $2(2)$ & $2(2)$ & $6(<1)$ & $6(<1)$ \\
Brachioteuthis?picta & $5(<1)$ & $5(2)$ & $12(2)$ & $12(3)$ & $3(2)$ & $3(3)$ & $34(4)$ & $34(5)$ \\
Histioteuthis sp. B & $2(<1)$ & $2(<1)$ & 0 & 0 & 0 & 0 & 0 & 0 \\
Unidentifiabie & $315(39)$ & 0 & $115(15)$ & 0 & $20(16)$ & 0 & $235(24)$ & 0 \\
Total & 837 & 274 & 773 & 444 & 123 & 99 & 973 & 634 \\
\hline
\end{tabular}

Table 2. Aptenodytes patagonicus. Percent occurrence of cephalopod species and estimated wet mass (g) of cephalopods represented by identifiable beaks in the stomach contents of $134 \mathrm{king}$ penguins at South Georgia during 4 austral summers (cephalopod species ranked in order of importance in terms of mass for all years combined; n: number of king penguins sampled; values in parentheses are percentages)

\begin{tabular}{|c|c|c|c|c|c|c|c|c|}
\hline Cephalopod species $\begin{array}{r}1 \\
\%\end{array}$ & $\begin{array}{l}\text { 1990/91 } \\
\text { occurrence }\end{array}$ & $\begin{array}{c}n=18 \\
\text { e Mass }\end{array}$ & $\begin{array}{c}1991 / 92 \\
\% \text { occurrence }\end{array}$ & $\begin{array}{l}n=67 \\
\text { Mass }\end{array}$ & $\begin{array}{c}\text { 1992/93 } \\
\text { \% occurrence }\end{array}$ & $\begin{array}{r}n=20 \\
\text { Mass }\end{array}$ & $\begin{array}{c}1993 / 94 \\
\% \text { occurrence }\end{array}$ & $\begin{array}{l}\mathrm{n}=34 \\
\text { Mass }\end{array}$ \\
\hline Martialia hyadesi & 95 & $28574(80)$ & 27 & $84309(74)$ & 15 & $6780(48)$ & 56 & $48875(57)$ \\
\hline Moroteuthis knipovitchi & 61 & $4290(12)$ & 36 & $13248(12)$ & 35 & $3236(23)$ & 68 & $14405(17)$ \\
\hline Kondakovia longimana & 78 & $826(2)$ & 39 & $5008(4)$ & 40 & $2322(16)$ & 74 & $11956(14)$ \\
\hline Psychroteuthis glacialis & 61 & $747(2)$ & 58 & $8724(8)$ & 50 & $1695(12)$ & 56 & $6633(8)$ \\
\hline Alluroteuthis antarcticus & is 6 & $1027(3)$ & 8 & $2081(2)$ & 5 & $140(1)$ & 32 & $3193(4)$ \\
\hline Gonatus antarcticus & 0 & 0 & 6 & $613(1)$ & 10 & $83(1)$ & 12 & $417(<1)$ \\
\hline Brachioteuthis ?picta & 22 & $29(<1)$ & 15 & $48(<1)$ & 10 & $9(<1)$ & 32 & $147(<1)$ \\
\hline Histioteuthis sp. B & 6 & $90(<1)$ & 0 & 0 & 0 & 0 & 0 & 0 \\
\hline Total & & 35582 & & 114030 & & 14263 & & 85627 \\
\hline
\end{tabular}

more, of those that were identified a relatively large proportion (28\%) were unmeasurable because of damage. No measurable beaks were unidentifiable; the only reason beaks could not be identified was because of their condition, not because they were from species that could not be recognised.

Overall, the commonest species of squid in the diet was Martialia hyadesi. In 1992/93, however, Kondakovia longimana and Psychroteuthis glacialis were more abundant. Of the squid taken by the penguins, 3 species, M. hyadesi, Gonatus antarcticus and Histioteuthis sp. B (probably $H$. eltaninae), have known distributions that extend as far north as the Subtropical Convergence; the other 5 species all have Antarctic or sub-Antarctic distributions (see Rodhouse et al. 1992a). All species are muscular and by inference strong swimmers. Of the 8 species of squid identified, only Brachioteuthis ?picta and Histioteuthis sp. B have photophores.

\section{Cephalopod mass}

Percent occurrence and wet mass data for squid in the diet of king penguins, for each year of the study, are shown in Table 2. Four species, Martialia hyadesi, Moroteuthis knipovitchi, Kondakovia longimana and Psychroteuthis glacialis, dominated the diet, contributing over $90 \%$ of the total mass in each year. These are all muscular species that grow to a relatively large size. By far the most important squid, in terms of wet mass, was $M$. hyadesi, although the proportion of penguins in which it was present varied between 95 and $15 \%$ over the 4 years of the study

\section{Presence of attached flesh}

The percentage of beaks, of each cephalopod species, with flesh attached is shown in Table 3 . The pres- 
Table 3. Aptenodytes patagonicus. Percentage of cephalopod beaks with flesh attached in the stomach contents of 134 king penguins sampled at South Georgia during 3 austral summers (cephalopods ranked in order of presence of flesh)

\begin{tabular}{|lrrrrr|}
\hline Cephalopod species & $1991 / 92$ & $1992 / 93$ & $1993 / 94$ & Mean \\
\hline Brachioteuthis ?picta & 50 & 67 & 65 & 61 \\
Psychroteuthis glacialis & 24 & 19 & 22 & 22 \\
Alluroteuthis antarcticus & 20 & 0 & 24 & 15 \\
Moroteuthis knipovitchi & 0 & 16 & 10 & 9 \\
Kondakovia longimana & 8 & 6 & 10 & 8 \\
Martialia hyadesi & 0 & 0 & 1 & 0 \\
Gonatus antarcticus & 0 & 0 & 0 & 0 \\
\hline
\end{tabular}

ence of flesh indicates that the squid was eaten relatively recently by the penguin. By ranking the cephalopods according to presence of flesh, it is possible to make a crude comparative estimate of distance offshore where the different species were caught, assuming similar rates of digestion. Most species are probably caught close to, or over, the South Georgia Shelf during summer. However, the data in Table 3 suggest that Martialia hyadesi and Gonatus antarcticus are caught at greater distances from the island.

\section{Size of cephalopods}

Mantle lengths of cephalopods consumed by king penguins, estimated from beak lengths, are shown in
Table 4. The largest squid in all years was $M$. hyadesi. Mantle lengths of this species fell in the range 155 to $355 \mathrm{~mm}$. Martialia hyadesi grows to a maximum ML of about 500 mm. Age data (Rodhouse 1991, Rodhouse et al. 1994b, Arkhipkin \& Silvanovich 1997) indicate that the specimens taken by king penguins are up to about 1 yr old and are probably at an early stage of sexual maturity. Gonatus antarcticus, Moroteuthis knipovitchi, Psychroteuthis glacialis, and Kondakovia longimana all grow to a large size 1350 to $900 \mathrm{~mm} \mathrm{ML}$. depending on species) and the specimens consumed were probably all juveniles. Alluroteuthis antarcticus, Brachioteuthis ?picta and Histioteuthis eltaninae are relatively small squid 166 and $270 \mathrm{~mm}$ ML respectively) and these too were probably immature at the time they were eaten. Within species, the size of squid taken in the different years did not vary substantially.

\section{Interannual variability}

Average cephalopod mass represented by beaks in each penguin stomach was estimated for the 4 years of the study (Table 5). This is the wet mass represented by the beaks, not the undigested material that was collected, and it only includes data from beaks that were in good enough condition to measure. The data therefore only represent squid that had been recently consumed, although they may represent more than 1 foraging trip, depending on the residence time of beaks in the stomach.

Table 4. Aptenodytes patagonicus. Lower rostral lengths (LRL, $\mathrm{mm}$ ) of cephalopod beaks (and estimated mantle lengths, ML, $\mathrm{mm}$ ) from the stomach contents of $134 \mathrm{king}$ penguins sampled at South Georgia during 4 austral summers (data in parentheses are the mid-range in cases where there were insufficient data to estimate the mode)

\begin{tabular}{|c|c|c|c|c|c|c|c|c|c|c|c|c|}
\hline \multirow{2}{*}{$\begin{array}{l}\text { Cephalopod } \\
\text { species }\end{array}$} & \multicolumn{3}{|c|}{$1990 / 91$} & \multicolumn{3}{|c|}{$1991 / 92$} & \multicolumn{3}{|c|}{$1992 / 93$} & \multicolumn{3}{|c|}{$1993 / 94$} \\
\hline & $\begin{array}{l}\text { Modal } \\
\text { LRL }\end{array}$ & $\begin{array}{l}\text { LRL } \\
\text { range }\end{array}$ & $\begin{array}{l}\text { Estimated } \\
\text { modal ML }\end{array}$ & $\begin{array}{l}\text { Modal } \\
\text { LRL }\end{array}$ & $\begin{array}{l}\text { LRL } \\
\text { range }\end{array}$ & $\begin{array}{l}\text { Estimated } \\
\text { modal ML }\end{array}$ & $\begin{array}{l}\text { Modal } \\
\text { LRL }\end{array}$ & $\begin{array}{c}\text { LRL } \\
\text { range }\end{array}$ & $\begin{array}{l}\text { Estimated } \\
\text { modal ML }\end{array}$ & $\begin{array}{l}\text { Modal } \\
\text { LRL }\end{array}$ & $\begin{array}{c}\text { LRL } \\
\text { range }\end{array}$ & $\begin{array}{l}\text { Estimated } \\
\text { modal ML }\end{array}$ \\
\hline $\begin{array}{l}\text { Martialia } \\
\text { hyadesi }\end{array}$ & 4.0 & $2.1-7.0$ & 220 & 6.0 & $3.6-8.4$ & 279 & 5.0 & $4.2-8.1$ & 249 & 4.5 & $1.8-8.6$ & 235 \\
\hline $\begin{array}{l}\text { Moroteuthis } \\
\text { knipovitchi }\end{array}$ & 5.0 & $2.8-6.2$ & 156 & 4.8 & $3.0-7.1$ & 137 & 4.5 & $2.5-5.9$ & 105 & 5.0 & $1.0-1.6$ & 1.56 \\
\hline $\begin{array}{l}\text { Kondakovia } \\
\text { longimana }\end{array}$ & 3.5 & $1.4-6.6$ & 89 & 6.5 & $2.2-9.6$ & 222 & 5.5 & $2.0-10.3$ & 178 & 3.5 & $1.0-10.5$ & 89 \\
\hline $\begin{array}{l}\text { Psychroteuthis } \\
\text { glacialis }\end{array}$ & 2.5 & $2.0-5.1$ & 51 & 4.5 & $0.9-5.7$ & 182 & 4.5 & $1.8-5.6$ & 182 & 4.5 & $1.7-7.0$ & 182 \\
\hline $\begin{array}{l}\text { Alluroteuthis } \\
\text { antarcticus }\end{array}$ & 6.9 & - & 211 & 5.5 & $4.0-7.0$ & 168 & 3.6 & - & 110 & 3.5 & $2.2-4.8$ & 107 \\
\hline $\begin{array}{l}\text { Gonatus } \\
\text { antarcticus }\end{array}$ & - & - & - & $(4.3)$ & $1.7-6.8$ & (141) & $(3.7)$ & $3.5-3.9$ & (115) & $(3.7)$ & $2.1-5.3$ & (115) \\
\hline $\begin{array}{l}\text { Brachioteuthis } \\
\text { ?picta }\end{array}$ & $(2.5)$ & $1.8-3.2$ & $(67)$ & (2) & $0.6-3.3$ & $(57)$ & $(1.4)$ & $1.2-1.6$ & $(45)$ & $(1.9)$ & $1.0-2.7$ & (55) \\
\hline $\begin{array}{l}\text { Histioteuthis } \\
\mathrm{sp} . \mathrm{B}\end{array}$ & $(2.6)$ & $2.5-2.7$ & $(44)$ & - & - & - & - & - & - & - & - & - \\
\hline
\end{tabular}


Table 5. Aptenodytes patagonicus. Annual variation in the estimated cephalopod mass (g) per penguin represented by beaks in the stomach contents (the \% column represents the percentage of total cephalopod mass represented by the 5 species in the table)

\begin{tabular}{|lccccccc|}
\hline Year & $\begin{array}{c}\text { Martialia } \\
\text { hyadesi }\end{array}$ & $\begin{array}{c}\text { Moroteuthis } \\
\text { knipovitchi }\end{array}$ & $\begin{array}{c}\text { Kondakovia } \\
\text { longimana }\end{array}$ & $\begin{array}{c}\text { Psychroteuthis } \\
\text { glacialis }\end{array}$ & $\begin{array}{c}\text { Alluroteuthis } \\
\text { antarcticus }\end{array}$ & Total \\
\hline $1990 / 91$ & 1587 & 238 & 45 & 420 & 57 & 1977 & $>99$ \\
$1991 / 92$ & 1258 & 198 & 75 & 130 & 31 & 702 & $>99$ \\
$1992 / 93$ & 339 & 161 & 116 & 85 & 7 & $>99$ & $>99$ \\
$1993 / 94$ & 1438 & 423 & 351 & 195 & 94 & 2518 \\
\hline
\end{tabular}

Total cephalopod mass represented by beaks varied by a factor of about 3.5 over the 4 years of the study and this was largely accounted for by variation in the amount of Martialia hyadesi consumed. The lowest quantities were present in the $1992 / 93$ season. This coincided with the year when the proportion by occurrence and mass of the myctophid Krefftichthys anderssoni in the diet of the penguins fell to the lowest levels observed in the study. It was replaced by Protomyctophum choriodon, especially at the end of the season (Olsson \& North 1997).

\section{King penguin foraging range in 1993/94}

The foraging ranges of the 4 satellite tracked penguins in 1993/94 are illustrated by the range polygons in Fig. 1. All 4 penguins foraged to the north of South Georgia up to a maximum distance of about $500 \mathrm{~km}$ from the breeding colony. The physical oceanography of the APFZ was well characterised in $1993 / 94$ by a shipboard oceanographic survey and remote sensed imagery, coincident with the penguin satellite tracking programme (Trathan et al. 1997). and so it is possible to relate the foraging range of the penguins to the major contemporary oceanographic features.

The APF was found to run to the south of the Maurice Ewing Bank and then curved northwards to the east of the Bank. The area to the east of the Bank was characterised by mesoscale features (meanders in the APF or warm core rings 80 to $140 \mathrm{~km}$ across) with anticyclonic rotation that were associated with the bathymetry of the Falkland Ridge. One of these features, centred at about $50^{\circ} 00^{\prime} \mathrm{S} 37^{\circ} 30^{\prime} \mathrm{W}$, was an area where satellite-tracked grey-headed albatrosses were preying on $M$. hyadesi (Rodhouse et al. 1996). The range polygons in Fig. 1 show that 2 of the penguins were foraging in this area of mesoscale activity; 1 of these 2 crossed to the north side of the APF whilst the other 3 ranged over a shorter distance and foraged over deep water between South Georgia and the APF. This is a highly variable oceanographic area where the
Weddell Scotia confluence passes to the north of South Georgia from the east. In 1994 the area was characterised by the presence of cold, relatively low salinity water.

\section{Total cephalopod consumption by king penguins}

Total food consumption by a single king penguin has been estimated to be ca $316 \mathrm{~kg} \mathrm{yr}^{-1}$ (Croxall et al. 1990). If the current estimate for the proportion of cephalopods in the diet during the breeding season (ca $3 \%$ ) applies throughout the year, total cephalopod consumption of cephalopods per bird would be some $9.4 \mathrm{~kg} \mathrm{yr}^{-1}$. During the present study the proportion of Martialia hyadesi in the diet fell in the range 48 to $80 \%$ (Table 2), so we can calculate that consumption of $M$. hyadesi was some 4.5 to $7.6 \mathrm{~kg} \mathrm{yr}^{-1}$ per bird and

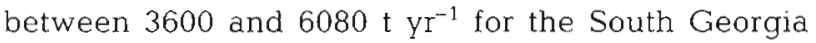
population of 400000 pairs during the present study.

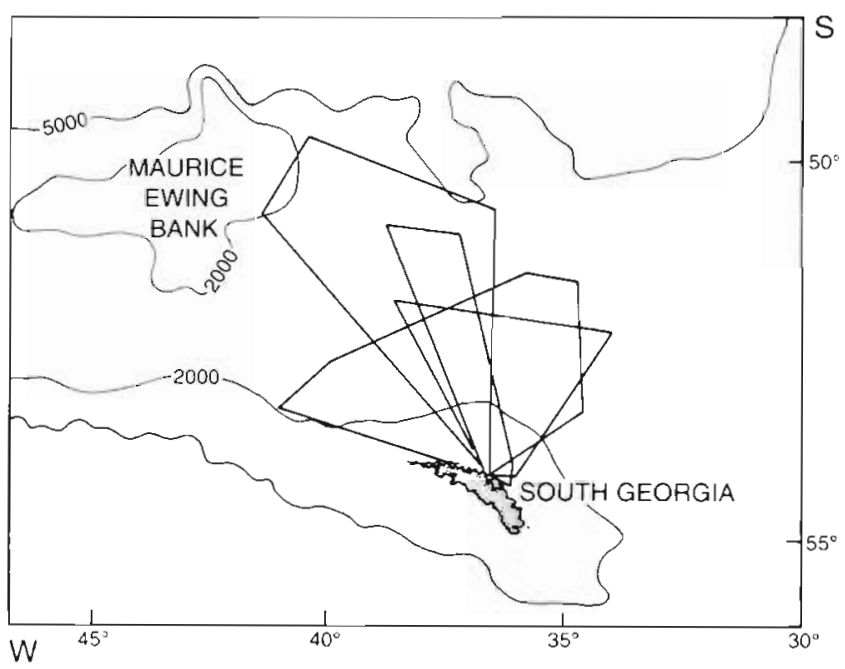

Fig. 1. Aptenodytes patagonicus. Antarctic Polar Frontal Zone to the north of South Georgia showing range polygons of 4 satellite tracked king penguins during the 1993/94 summer (maps based on British Admiralty Chart number 4024) 


\section{DISCUSSION}

This paper deals exclusively with the cephalopod prey of king penguins, which contributed about $3 \%$ of the total diet at South Georgia during the study period. The cephalopods were dominated by the ommastrephid squid Martialia hyadesi from the same size range as $M$. hyadesi caught by the commercial fishery in the South Atlantic (Rodhouse 1991). The distribution of this squid is primarily associated with the APFZ (Rodhouse in press), but it is known to occur closer to South Georgia during the austral winter (Gonzalez \& Rodhouse 1998j. The other squid species are all known from the South Georgia area. They have been caught with scientific and commercial gear (Rodhouse 1990), and they occur in the diet of several higher predators breeding on the island (Rodhouse et al. 1987, 1990, 1992a, 1993, Croxall et al. 1995). Most have typically pelagic distributions although larger specimens of Moroteuthis ingens and Psychroteuthis glacialis than those found in the penguin stomach contents have been caught in bottom trawls (Rodhouse 1989). The presence of flesh on beaks of all species except those of $M$. hyadesi and Gonatus antarcticus suggests that the relatively small numbers of these species are caught close to the breeding colony. The absence of flesh from virtually all $M$. hyadesi suggests that this species does not occur close to South Georgia during the austral summer and is probably caught by the penguins while they are foraging close to the APFZ.

In $1992 / 93$ squid were less important in the diet than in other years due to a substantial decrease in the amount of Martialia hyadesi. This coincided with a change in the dominant fish in the diet from Krefftichthys anderssoni to Protomyctophum choriodon. An analysis of the diet of $M$. hyadesi in 1989 at the APFZ showed that $K$. anderssoni was the most important prey, and so the reduction in both of these species in 1992/93 may well have been linked. Given the relatively minor importance of cephalopods in the diet of king penguins during the summer at South Georgia, we conclude that the penguins are primarily targeting myctophids and that squid are incidental in the diet.

The 1992/93 season, when less squid were consumed, corresponded with a period of relatively high krill abundance at South Georgia (Croxall et al. 1997. Reid et al. 1997). Although king penguins are not krill predators, changes in the relative abundance of krill may indicate other changes in the ecosystem that the penguins respond to. In 1993/94 krill was particularly scarce (Brierley \& Watkins 1996) and in that year the mean duration of penguin foraging trips was significantly increased and, in common with other predators, breeding success was much reduced (Boyd et al. 1995, Olsson 1997. Olsson \& Brodin 1997).
The estimate of total annual cephalopod consumption by king penguins from the South Georgia colony might be low if they consume a higher proportion of squid out of the breeding season, as has been shown for king penguins in the Indian Ocean sector (Adams \& Klages 1987, Cherel et al. 1996).

Acknowledgements. We thank the British Antarctic Survey, the Swedish Antarctic Research Program and the Swedish Natural Science Research Council for support of this collaborative research. Phil Trathan and John Croxall made many helpful comments and suggestions at the manuscript stage.

\section{LITERATURE CITED}

Adams NJ, Klages NT (1987) Seasonal variation in the diet of the king penguin (Aptenodytes patagonicus) at subAntarctic Marion Island. J Zool Lond 212:303-324

Arkhipkin Al, Silvanovich NV (1997) Age, growth and maturation of the squid Martialia hyadesi (Cephalopoda, Ommastrephidae) in the south-west Atlantic. Antarct Sci $9: 373-380$

Boyd IL, Croxall JP, Lunn NJ, Reid K (1995) Population demography of Antarctic fur seals: the costs of reproduction and implications for life-histories. J Anim Ecol 64: $505-518$

Brierley AS, Watkins JL (1996) Acoustic targets at South Georgia and the South Orkney Islands during a season of krill scarcity. Mar Ecol Prog Ser 138:51-61

Cherel Y, Ridoux V, Rodhouse PG (1996) Fish and squid in the diet of king penguin chicks, Aptenodytes patagonicus, during winter at sub-Antarctic Crozet Islands. Mar Biol 126:559-570

Clarke MR (1986) A handbook for the identification of cephalopod beaks. Clarendon Press, Oxford

Croxall JP, Rickets C, Wood AG (1990) Food consumption by predators in a CCAMLR integrated study region. Ninth meeting of the Scientific Committee of the Commission for the Conservation of Antarctic Marine Living Resources. Hobart, Australia. SC-CCAMLR-14/BG/16

Croxall JP, Hall AJ, Hill HJ, North AW, Rodhouse PG (1995) The food and feeding ecology of the white-chinned petrel Procellaria aequinoctialis at South Georgia. J Zool Lond 237:133-150

Croxall JP, McCann TS, Prince PA, Rothery P (1988) Reproductive performance of seabirds and seals at South Georgia and Signy Island, South Orkney Islands, 1976-1987. implications for Southern Ocean monutoring studies. In: Sahrhage D (ed) Antarctic ocean and resources variability. Springer-Verlag, Berlin, p 261-285

Croxall JP, Prince PA, Reid K (1997) Dietary segregation in South Georgia seabirds. J Zool Lond 242:531-556

González AF, Rodhouse PG (1998) Fishery biology of the seven star flying squid Martialia hyadesi at South Georgia during winter. Polar Biol 19:231-236

Hempel $G$ (1985) On the biology of the Polar Seas, particularly the Southern Ocean. In: Gray JS, Christiansen ME (eds) Marine biology of polar regions and effects of stress on marine organisms. John Wiley, Chichester, p 3-34

Hindell MA (1988) The diet of king penguin Aptenodytes patagonicus at Macquarie Island. Ibis 130:193-203

Jouventin P, Capdeville D, Cuénot-Chaillet F, Boiteau C (1994) Exploitation of pelagic resources by a non-flying seabird: satellite tagging of the king penguin throughout 
the breeding cycle. Mar Ecol Prog Ser 106:11-19

Kooyman GL, Cherel Y, Le Maho Y, Croxall JP, Thorson PH, Ridoux V, Kooyman CA (1992) Diving behavior and energetics during foraging cycles in king penguins. Ecol Monogr 62:143-163

McConnell BJ, Fedak MA (1996) Movements of southern elephant seals. Can J Zool 74:1485-1496

Olsson O (1997) Effects of food availability on fledging condition and post fledging survival in king penguin chicks Polar Biol 18:161-165

Olsson O, Brodin A (1997) Changes in king penguin breeding cycle in response to food availabilty. Condor 99:994-997

Olsson O, North AW (1997) Diet of the king penguin Aptenodytes patagonicus during three summers at South Georgia. Ibis 139:504-513

Pagès $F$, White $M G$, Rodhouse PG (1996) Dominance of gelatinous carnivores in the nekton community of the Antarctic Polar Frontal Zone in summer 1994. Mar Ecol Prog Ser 141:139-147

Piatkowski U, Rodhouse PG, White MG, Bone DG, Symon C (1994) Nekton community of the Scotia Sea as sampled by the RMT25 during austral summer. Mar Ecol Prog Ser 112: $13-28$

Prince PA, Croxall JP, Trathan PN, Wood AG (1997) The pelagic distribution of South Georgia albatrosses and their relationships with fisheries. In: Robertson G, Gales R (eds) Albatross biology and conservation. Surrey Beatty \& Sons, Chipping Norton, Australia, p 137-167

Prince PA, Wood AG, Barton T, Croxall JP (1992) Satellite tracking of wandering albatrosses (Diomedea exulans) in the South Atlantic. Antarct Sci 4:31-36

Reid K, Croxall JP, Edwards TM (1997) Interannual variation in the diet of the Antarctic prion Pachyptila desolata at South Georgia. Emu 97:126-132

Rodhouse PG (1989) Pelagic cephalopods caught by nets during the Antarctic research cruises of the Polarstern and Walther Herwig, 1984-87. Arch FischWiss 39:111-121

Rodhouse PG (1990) Cephalopod fauna of the Scotia Sea at South Georgia: potential for commercial exploitation and possible consequences. In: Kerry K, Hempel G (eds) Antarctic ecosystems. Ecological change and conservation. Springer-Verlag, Berlin, p 289-298

Rodhouse PG (1991) Population structure of Martialia hyadesi (Cephalopoda: Ommastrephidae) at the Antarctic Polar Front and the Patagonian Shelf. Bull Mar Sci 49 $404-418$

Editorial responsibility: Otto Kinne (Editor),

Oldendorf/Luhe, Germany
Rodhouse PG (1997) Precautionary measures for a new Martialia hyadesi (Cephalopoda, Ommastrephidae) fishery in the Scotia Sea: an ecological approach. CCAMLR Science $4: 125-139$

Rodhouse PG (in press) Large and meso-scale distribution of the ommastrephid squid Martialia hyadesi in the Southern Ocean: a synthesis of information relevant to fishery forecasting and management. Korean J Polar Res

Rodhouse PG, Arnbom TR, Fedak MA, Yeatman J, Murray AWA (1992a) Cephalopod prey of the southern elephant seal Mirounga leonina L. Can J Zool 70:1007-1015

Rodhouse PG, Clarke MR, Murray AWA (1987) Cephalopod prey of the wandering albatross Diomedea exulans. Mar Biol 96:1-10

Rodhouse PG, Piatkowski U, Murphy EJ, White MG, Bone DG (1994a) Utility and limits of biomass spectra: the nekton community sampled with the RMT25 in the Scotia Sea during austral summer. Mar Ecol Prog Ser 112:29-39

Rodhouse PG, Prince PA (1993) Cephalopod prey of the black-browed albatross Diomedea melanophrys at South Georgia. Polar Biol 13:373-376

Rodhouse PG, Prince PA, Clarke MR, Murray AWA (1990) Cephalopod prey of the grey-headed albatross Diomedea chrysostoma. Mar Biol 104:353-362

Rodhouse PG, Prince PA, Trathan PN, Hatfield EMC, Watkins JL, Bone DG, Murphy EJ, White MG (1996) Cephalopods and mesoscale oceanography at the Antarctic Polar Front: satellite tracked predators locate pelagic trophic interactions. Mar Ecol Prog Ser 136:37-50

Rodhouse PG, Robinson K, Gajdatsy SB, Daly HI, Ashmore MJS (1994b) Growth, age structure and environmental history in the cephalopod Martialia hyadesi (Teuthoidea: Ommastrephidae) at the Antarctic Polar Frontal Zone and on the Patagonian Shelf edge. Antarct Sci 6:259-267

Rodhouse PG, White MG (1995) Cephalopods occupy the ecological niche of epipelagic fish at the Antarctic Polar Frontal Zone. Biol Bull (Woods Hole) 189:77-80

Rodhouse PG, White MG, Jones MRR (1992b) Trophic relations of the cephalopod Martialia hyadesi (Teuthoidea: Ommastrephidae) at the Antarctic Polar Front. Mar Biol 114:415-421

Trathan PN, Brandon MA, Murphy EJ (1997) Characterisation of the Antarctic Polar Frontal Zone to the north of South Georgia in summer 1994. J Geophys Res 102:10483-10497

Wilson RP (1984) An improved stomach pump for penguins and other seabirds. J Field Ornithol 55:109-112

Submitted: January 20, 1998; Accepted: May 13, 1998

Proofs recerved from author(s): June 15, 1998 